\title{
Nucleofection Efficiency of Sheep Primary Fibroblasts Established from Refrigerated Skin
}

\author{
Mahipal Singh ${ }^{1} \&$ Xiaoling $\mathrm{Ma}^{1}$ \\ ${ }^{1}$ Animal Science Division, Agricultural Research Station, Fort Valley State University, Fort Valley, GA 31030, USA \\ Correspondence: Mahipal Singh, Animal Science Division, Agricultural Research Station, Fort Valley State \\ University, Fort Valley, GA 31030, USA. E-mail: singhm@fvsu.edu
}

Received: May 21, 2018

Accepted: June 20, 2018

Online Published: July 27, 2018

doi:10.5539/ijb.v10n4p12

URL: https://doi.org/10.5539/ijb.v10n4p12

\begin{abstract}
Dermal fibroblasts are useful for production of genetically engineered biologically active factors for development of cellular therapies and tissue engineering products for regenerative medicine. However, their transfection efficiencies using traditional non-viral methods are low and vary based on cell-type and species-specific differences. Using nucleofection technology, here we show that the transfection efficiency of primary fibroblasts established after 0-, 35-, and 65-days of postmortem storage of sheep skin tissues in a refrigerator was $59.49 \% \pm$ $9.66 \%, 59.33 \% \pm 11.59 \%$, and $43.48 \% \pm 8.09 \%$ respectively, as determined by analysis of green fluorescent protein (GFP) expression.
\end{abstract}

Keywords: primary cells, dermal fibroblasts, nucleofection, GFP, sheep skin, postmortem storage

\section{Introduction}

Nucleofection is a powerful electroporation-based technique to transfer nucleic acids (DNA, RNA) into cells (Trompeter, Weinhold, Thiel, Wernet, \& Uhrberg, 2003). It has been used for gene delivery in difficult-to-transfect mammalian cells such as primary cells, neurons, and resting blood cells (Keller, Maess, Schnoor, Scheiding, \& Lorkowski, 2018; Lai, Chang, \& Farber, 2003; Maurisse et al., 2010; Nakayama et al., 2007; Zeitelhofer et al., 2007). Primary cells are freshly isolated from body tissues and closely resemble the in-vivo situation, and for this reason they are of particular interest in biomedical research. Nucleofection is performed by an electrical device called "Nucleofector" which uses a combination of electrical parameters and cell-type specific reagents. Here DNA, RNA or siRNA is directly transferred into the cell nucleus, unlike the commonly used non-viral transfection methods, which rely upon cell division for the DNA or RNA transfer into the nucleus (Jacobsen et al., 2006). Thus, nucleofection provides the ability to transfect even non-dividing cells (Trompeter et al., 2003). Traditionally, gene transfer into primary cells has been achieved by use of viral vectors. However, use of such vectors involves safety risks, high cost, and lack of reliability (Liu \& Wang, 2015). The non-viral gene transfer methods are not suitable for the efficient transfection of primary cells, including dermal fibroblasts, which are abundantly found in mammalian skin. Fibroblasts are a powerful tool for the study of ex-vivo delivery of nucleic acids, including genes for therapeutic proteins, to design cellular therapies and tissue engineering products (Dickens et al., 2010; Koster \& Waterham, 2017; Zhang et al., 2011). However, their transfection efficiencies, using non-viral methods, are low and vary for different cell types and species, necessitating their prior optimization for the desired species/cell type. Here we show efficient transfection of sheep dermal primary fibroblasts using nucleofector technology.

\section{Material and Methods}

\subsection{Preparation of Primary Cells and Cell Culture}

Three different cell-lines were established from postmortem sheep ear skin tissues stored in a lab refrigerator as described before (Singh, Ma, Amoah, \& Kannan, 2011). Briefly, small 2-3 $\mathrm{mm}^{2}$ explants were excised from the tissue after 0-, 35- and 65-days of postmortem (dpm) storage. The explants were adhered in $60 \mathrm{~mm}$ diameter dishes and cultured in Dulbecco's Modified Eagles Medium (DMEM) with 10\% fetal bovine serum (FBS), 50 units $/ \mathrm{mL}$ of penicillin, $50 \mu \mathrm{g} / \mathrm{mL}$ of streptomycin and $2.5 \mu \mathrm{g} / \mathrm{mL}$ of fungizone. The outgrowing cells were recovered after 10 days of culture by trypsinization, suspended in Synth-a-Freeze ${ }^{\circledR}$ (Life Technologies Corp., Carlsbad, CA) media, aliquoted into cryovials $\left(1.0 \times 10^{5}\right.$ cells / vial $)$ and frozen at $-80^{\circ} \mathrm{C}$ deep freezer o/n using Nalgene ${ }^{\mathrm{TM}}$ Cryo $1{ }^{\circ} \mathrm{C}$ 
Freezing Container (Nalgene, Rochester, NY). Next day the vials were transferred to liquid nitrogen tank for storage until used. For experiments the frozen cell vials were taken out of liquid nitrogen, passaged once, and used at $70-80 \%$ confluence level.

\subsection{Nucleofection Procedure}

Nucleofection was performed using 4D-Nucleofector System, reagents, and the manufacturer's guidelines (Lonza, Walkersville Inc., Koeln, Germany). Briefly, 250,000 cells were mixed in $20 \mu \mathrm{L}$ of nucleofactor-solution complex $(16.4 \mu \mathrm{L}$ P3 nucleofactor solution $+3.6 \mu \mathrm{L}$ of P3 supplement) for each sample. Subsequently, $0.5 \mu \mathrm{L}(0.5 \mu \mathrm{g})$ of pmaxGFP plasmid DNA (Lonza, Walkersville Inc., Koeln, Germany) was added to each experimental tube (except negative plasmid DNA control tube), mixed gently and the cells were transferred to the corresponding labeled wells in a 16-well nucleocuvette strip and nucleoporated using 4D-Nucleofector System and the COS 7 program (Lonza, Walkersville Inc., Koeln, Germany). Following the nucleoporation, the cells were transferred to the labelled corresponding wells of a 24 -well microtiter plate containing $500 \mu \mathrm{L}$ pre-equilibrated warm media. The microtiter plate was incubated at $37^{\circ} \mathrm{C}$ in a humidified $\mathrm{CO}_{2}$ incubator. After $48 \mathrm{~h}$ of culture these microtiter plates were observed in EVOS fluorescence microscope using GFP filter.

\subsection{Cell Counting and Analysis}

The number of cells was counted in Countess II FL Automated Cell Counter (Thermo Fisher Scientific) using the GFP light cube. Each sample was analyzed in triplicate and their mean and standard deviation (SD) was determined using Excel Program. Transfection efficiency was calculated as percent of GFP positive cells in total cells counted. Statistical significance was assessed using One-Way ANOVA at $\mathrm{p}<.05$. (http://www.socscistatistics.com/tests/anova/default2.aspx)

\section{Results and Discussion}

The goal of this study was to determine, if the primary cells derived from sheep skin stored in refrigerator for different time intervals can be transfected effectively by Amaxa nucleofection system. Using the standard protocol and COS 7 program, we observed that the GFP gene containing plasmid DNA when transferred into primary fibroblast cells using a nucleofection technology expressed in all 3 sheep cell-lines tested, irrespective of their postmortem time interval between animal slaughter and cell culture from refrigerated explants (Table 1, Figure 1). Cells that did not receive GFP plasmid DNA exhibited no green fluorescence (Figure 1, no GFP plasmid control panel). Transfection efficiency of primary fibroblasts established after $0-, 35-$, and 65 -days of postmortem tissue storage was $59.49 \% \pm 9.66 \%, 59.33 \% \pm 11.59 \%$, and $43.48 \% \pm 8.09 \%$ respectively, as determined by analysis of green fluorescent protein (GFP) expression (Table 1, Figure 2). Although, the number of cells expressing GFP gene was reduced in 65-dpm cell-line as compared to 0-dpm and 35-dpm cell-lines, it was not significantly different $(\mathrm{p}<.05)$ as determined by One-Way ANOVA analysis of the results. The intensity of the green fluorescence was variable among different cells of a cell population, irrespective of the cell-line. Some of the cells show very intense color while others show diffused and less intense coloration. Such variability of GFP expression in mammalian cells has been shown earlier (Maurisse et al., 2010). Mammalian skin is the richest source of fibroblast cells and is easily accessible without complicated surgical procedures and thus is an ideal source of fibroblast cells. It is an important source of biodiversity conservation for long term storage in veterinary science and animal agriculture. Additionally, they are potentially important for production of genetically engineered therapeutic products for systemic release or transplantation cellular therapies, to treat mammalian diseases. They are also commonly used as feeder layers for growing embryonic stem cells. In conclusion, the knowledge gained about the transfection efficiency of primary fibroblasts of sheep by using nucleofection will help utilize stored tissue derived primary cells for genetic engineering and animal cloning as well as for cellular therapies.

Table 1. Quantification of GFP Positive Cells in Different Fibroblast Cell Lines after $48 \mathrm{~h}$ of Nucleofection

\begin{tabular}{cllll}
\hline \multirow{2}{*}{ GFP plasmid DNA } & \multirow{2}{*}{ Cell line } & \multicolumn{3}{c}{ Mean \pm SD } \\
\cline { 3 - 5 } & & Total cells* $\left(\times 10^{5}\right)$ & GFP positive cells* $\left(\times 10^{5}\right)$ & $\%$ GFP positive \\
\hline+ & 0 -dpm & $8.41 \pm 0.86$ & $4.95 \pm 0.30$ & $59.49 \pm 9.66$ \\
+ & 35 -dpm & $11.73 \pm 1.75$ & $7.04 \pm 2.03$ & $59.33 \pm 11.59$ \\
+ & $65-\mathrm{dpm}$ & $11.8 \pm 0.40$ & $5.59 \pm 0.43$ & $43.48 \pm 8.09$ \\
- & $65-\mathrm{dpm}$ (control) & $11.15 \pm 1.06$ & $0.00 \pm 0.00$ & $0.00 \pm 0.00$ \\
\hline
\end{tabular}

*cells are per ml 


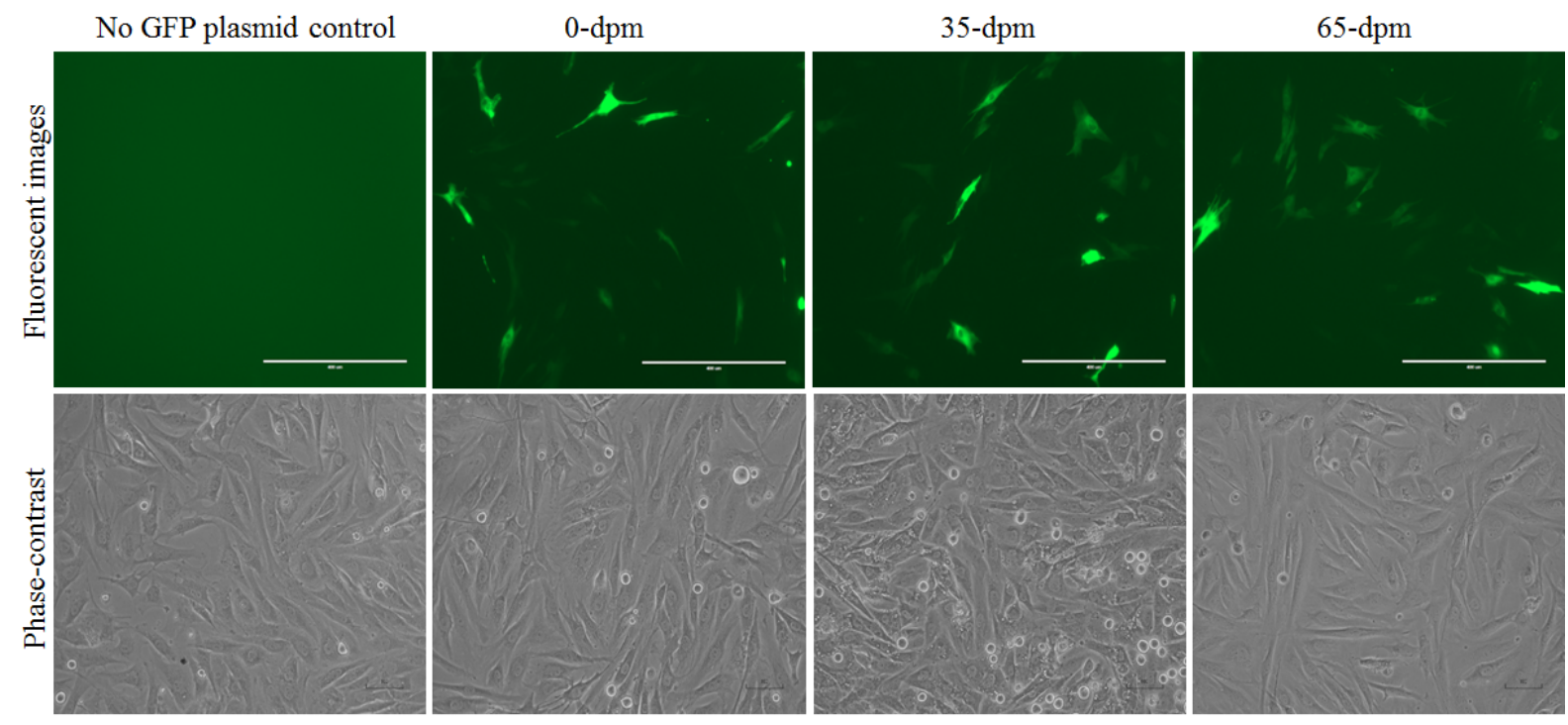

Figure 1. Expression of GFP gene after $48 \mathrm{~h}$ of nucleofection in three different cell lines

The cells were nucleofected with or without pmaxGFP plasmid DNA and visualized after $48 \mathrm{~h}$ under EVOS fluorescence microscope using GFP filter. Scale bars, GFP panels $=400 \mu \mathrm{m}$; light microscopic phase contrast panels $=100 \mu \mathrm{m}$. Magnification, $\mathrm{x} 400$ for GFP, and x200 for light microscopic phase contrast images.

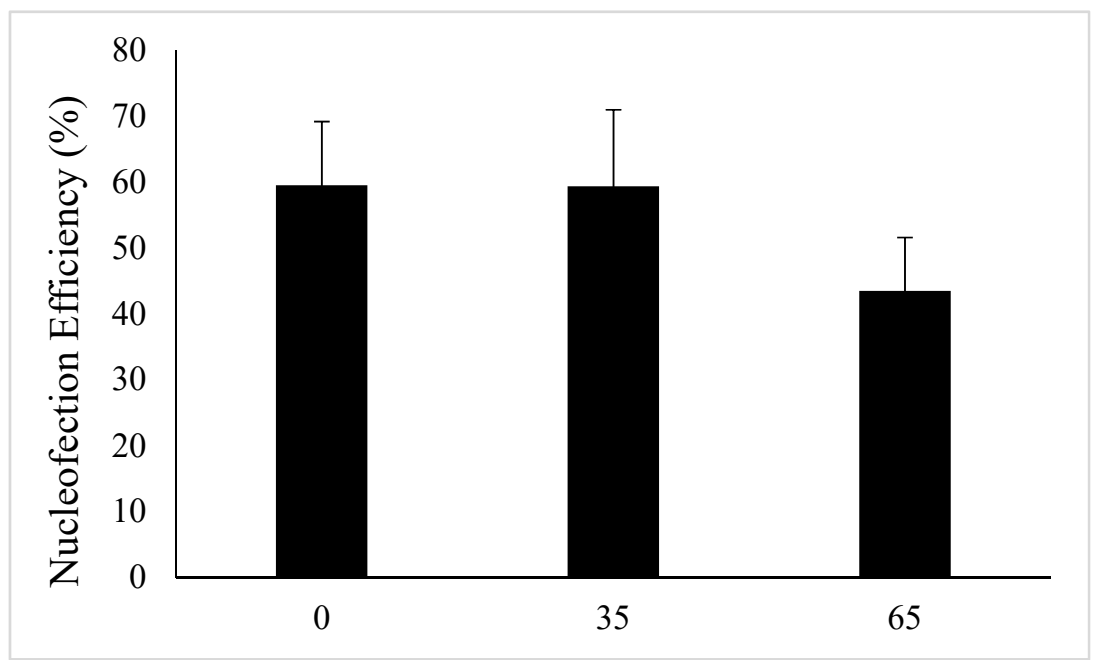

Figure 2. Quantification of GFP expressing cells in 0-dpm, 35-dpm, and 65-dpm cell-lines. Results are depicted as mean $\pm \mathrm{SD}$

\section{Acknowledgements}

This work was supported by the USDA-National Institute of Food and Agriculture, Evans-Allen project number 1009701 to Dr. Mahipal Singh.

\section{References}

Dickens, S., Van den Berge, S., Hendrickx, B., Verdonck, K., Luttun, A., \& Vranckx, J. J. (2010). Nonviral transfection strategies for keratinocytes, fibroblasts, and endothelial progenitor cells for ex vivo gene transfer to skin wounds. Tissue Engineering.Part C, Methods, 16(6), 1601-1608. https://doi.org/10.1089/ten.tec. 2009.0648 
Jacobsen, F., Mertens-Rill, J., Beller, J., Hirsch, T., Daigeler, A., \& Langer, S. (2006). Nucleofection: A new method for cutaneous gene transfer? Journal of Biomedicine \& Biotechnology, 2006(5), 26060. https://doi.org/10.1155/JBB/2006/26060

Keller, A. A., Maess, M. B., Schnoor, M., Scheiding, B., \& Lorkowski, S. (2018). Transfecting macrophages. Methods in Molecular Biology (Clifton, N.J.), 1784, 187-195. https://doi.org/10.1007/978-1-4939-7837-3_18

Koster, J., \& Waterham, H. R. (2017). Transfection of primary human skin fibroblasts for peroxisomal studies. Methods in Molecular Biology (Clifton, N.J.), 1595, 63-67. https://doi.org/10.1007/978-1-4939-6937-1_7

Lai, W., Chang, C. H., \& Farber, D. L. (2003). Gene transfection and expression in resting and activated murine CD4 T cell subsets. Journal of Immunological Methods, 282(1-2), 93-102. https://doi.org/10.1016/j.jim.2003. 07.015

Liu, Y., \& Wang, D. A. (2015). Viral vector-mediated transgenic cell therapy in regenerative medicine: Safety of the process. Expert Opinion on Biological Therapy, 15(4), 559-567. https://doi.org/10.1517/14712598.2015. 995086

Maurisse, R., De Semir, D., Emamekhoo, H., Bedayat, B., Abdolmohammadi, A., Parsi, H., et al. (2010). Comparative transfection of DNA into primary and transformed mammalian cells from different lineages. BMC Biotechnology, 10, 9-6750-10-9. https://doi.org/10.1186/1472-6750-10-9

Nakayama, A., Sato, M., Shinohara, M., Matsubara, S., Yokomine, T., \& Akasaka, E. (2007). Efficient transfection of primarily cultured porcine embryonic fibroblasts using the amaxa nucleofection system. Cloning and Stem Cells, 9(4), 523-534. https://doi.org/10.1089/clo.2007.0021

Singh, M., Ma, X., Amoah, E., \& Kannan, G. (2011). In vitro culture of fibroblast-like cells from postmortem skin of katahdin sheep stored at 4 degrees $\mathrm{C}$ for different time intervals. In Vitro Cellular \& Developmental Biology.Animal, 47(4), 290-293. http://doi.org/10.1007/s11626-011-9395-6

Trompeter, H. I., Weinhold, S., Thiel, C., Wernet, P., \& Uhrberg, M. (2003). Rapid and highly efficient gene transfer into natural killer cells by nucleofection. Journal of Immunological Methods, 274(1-2), 245-256. https://doi.org/10.1016/S0022-1759(02)00431-3

Zeitelhofer, M., Vessey, J. P., Xie, Y., Tubing, F., Thomas, S., Kiebler, M., et al. (2007). High-efficiency transfection of mammalian neurons via nucleofection. Nature Protocols, 2(7), 1692-1704. https://doi.org/10. 1038/nprot.2007.226

Zhang, Z., Slobodianski, A., Ito, W. D., Arnold, A., Nehlsen, J., Weng, S., et al. (2011). Enhanced collateral growth by double transplantation of gene-nucleofected fibroblasts in ischemic hindlimb of rats. PloS One, 6(4), e19192. https://doi.org/10.1371/journal.pone.0019192

\section{Copyrights}

Copyright for this article is retained by the author(s), with first publication rights granted to the journal.

This is an open-access article distributed under the terms and conditions of the Creative Commons Attribution license (http://creativecommons.org/licenses/by/4.0/). 